\title{
Kinetic control on the formation of tooeleite, schwertmannite and jarosite by Acidithiobacillus ferrooxidans strains in an As(III)-rich acid mine water
}

\author{
Marion Egal ${ }^{\mathrm{a}, *}$, Corinne Casiot ${ }^{\mathrm{a}}$, Guillaume Morin ${ }^{\mathrm{b}}$, Marc Parmentier ${ }^{\mathrm{c}}$, Odile Bruneel ${ }^{\mathrm{a}}$, \\ Sophie Lebrun ${ }^{\mathrm{b}}$, Françoise Elbaz-Poulichet ${ }^{\mathrm{a}}$ \\ a Laboratoire Hydrosciences Montpellier, UMR 5569 CNRS-IRD-UM1E2, Université Montpellier 2, Place E. Bataillon, Case MSE, 34095 Montpellier cedex 05, France \\ ${ }^{\mathrm{b}}$ Laboratoire de Minéralogie-Cristallographie, UMR CNRS 7590, Universités Paris 6 et 7, et IPGP, 4 Place Jussieu 75252 Paris Cedex 05, France \\ ' BRGM, service Eau/M2H, 3 avenue Claude Guillemin, BP 36009, 45060 Orléans Cedex 2, France
}

\begin{abstract}
A B S T R A C T
Trapping of arsenic(III) by $\mathrm{Fe}(\mathrm{III})$-minerals during microbial Fe(II) oxidation was investigated in cultures of various Acidithiobacillus ferrooxidans strains. Each strain, known to be unable to oxidize As(III), was inoculated in sterilized acid mine drainage water containing hundreds of mg per litre of $\mathrm{Fe}(\mathrm{II})$ and tens $\mathrm{mg}$ per litre levels of arsenic, mainly in the As(III) form. Iron and arsenic speciation were followed in the dissolved phase, and microbial Fe(II) oxidation products were identified using XRD and EXAFS spectroscopy. Arsenite was found to coprecipitate with amorphous phases, with schwertmannite, and/or to be incorporated in tooeleite $\left(\mathrm{Fe}_{6}\left(\mathrm{AsO}_{3}\right)_{4} \mathrm{SO}_{4}(\mathrm{OH})_{4} \cdot \mathrm{H}_{2} \mathrm{O}\right)$. Precipitation of As-poor jarosite also occurred at the end of the experiments. The nature, proportion and sequence of the biominerals differed from one strain to another and as a function of the inoculum size. This appeared to be related to the kinetic of Fe precipitation during the early stage of incubation. As(III)-rich schwertmannite formed when the lag period was lower than one day, while tooeleite formed during extended ( $\geq 9$ days) lag period. After more than 15 days, jarosite precipitated upon complete $\mathrm{Fe}$ (II) oxidation, in agreement with the highest thermodynamic stability of this phase. This mineral did not trap significant amounts of As(III). Neither tooeleite nor As(III)-rich schwertmannite formed without bacteria in the AMD water used in this study.
\end{abstract}

Keywords:

Acidithiobacillus ferrooxidans

Acid mine drainage (AMD)

Arsenic

Tooeleite

\section{Introduction}

The weathering of tailings originating from the mining of metallic sulphide ores results in the formation of acid effluents called acid mine drainage (AMD). They contain extremely high concentrations of dissolved iron, sulphate and toxic elements such as arsenic (Filipek et al., 1987; Lopez-Archilla et al., 2001; Olías et al., 2006). Nordstrom and Alpers (1999) have evidenced $\mathrm{pH}$ values as low as -3.6 combined with very high concentrations of metal $(200 \mathrm{~g} / \mathrm{l})$ and sulphate salts (760 g/l). AMD generation can persist hundreds of years after the mine closed (Demchak et al., 2004) causing deleterious effects on water resources and on aquatic life. The scale of the pollution is difficult to assess accurately, but it is considered as a severe environmental problem worldwide (Nordstrom and Alpers, 1999; Younger and Robins, 2002; Johnson and Hallberg, 2005) and references cited therein). Orange Fe precipitates are ubiquitous in the acid waters (Filipek et al., 1987). They consist of a variety of iron (oxyhydr)oxides and hydroxysulfates such as jarosite $\left(\mathrm{KFe}_{3}\left(\mathrm{SO}_{4}\right)_{2}\right.$ $\left.(\mathrm{OH})_{6}\right)$, schwertmannite $\mathrm{Fe}_{8} \mathrm{O}_{8}(\mathrm{OH})_{6} \mathrm{SO}_{4}$, ferrihydrite $\left(\mathrm{Fe}_{5} \mathrm{HO}_{8} .4 \mathrm{H}_{2} \mathrm{O}\right)$, goethite $(\alpha-\mathrm{FeOOH})$ and lepidocrocite $(\gamma-\mathrm{FeOOH})$, which precipitate

\footnotetext{
* Corresponding author. Tel.: +33 467143659; fax: +33 467144774. E-mail address: egal@msem.univ-montp2.fr (M. Egal).
}

as the $\mathrm{pH}$ rises (Bigham et al., 1996). These sediments are able to immobilize arsenic by sorption or coprecipitation reactions (Morin and Calas, 2006). The formation of these minerals is enhanced by the metabolic activity of bacteria such as Acidithiobacillus ferrooxidans that catalyze the oxidation of $\mathrm{Fe}(\mathrm{II})$ into $\mathrm{Fe}(\mathrm{III})$ by dissolved $\mathrm{O}_{2}$. A strain of $A$. ferrooxidans was shown to promote the formation of tooeleite, an $\mathrm{As}$ (III)$\mathrm{Fe}(\mathrm{III})$ mineral $\left(\mathrm{Fe}_{6}\left(\mathrm{AsO}_{3}\right)_{4} \mathrm{SO}_{4}(\mathrm{OH})_{4} \cdot 4 \mathrm{H}_{2} \mathrm{O}\right)$ which has been identified as the main constituent of stromatolite-like deposits in the exceptionally As (III)-rich Carnoulès AMD (Gard, France) (Morin et al., 2003; Morin and Calas, 2006). The formation of this phase decreases drastically the concentration of $\mathrm{As}(\mathrm{III})$ that reaches the Amous river downstream the Carnoulès mine (Casiot et al., 2003, 2005).

In the present work, we investigated biological factors (different strains of $A$. ferrooxidans and different cell concentrations) that may control tooeleite formation. Strains of $A$. ferrooxidans were grown in monoxenic cultures in the Carnoulès AMD water. The rate of Fe and As precipitation and the mineralogy of the neo-formed solid phases were monitored for one month. The results of this study could be useful for the implementation of bioremediation processes applied to As(III)contaminated acidic waters. Indeed, the rate-limiting factors in passive biological AMD remediation systems is often the numbers and species of iron-oxidising prokaryotes, each having possibly different affinities for ferrous iron, temperature and $\mathrm{pH}$ optima 
Table 1

Composition of the filtered Carnoulès AMD water used for the two series of bioassays.

\begin{tabular}{llll}
\hline & October 2004 & May 2007 \\
\hline $\mathrm{pH}$ & 3,4 & 460 & 3,2 \\
$\mathrm{Eh}(\mathrm{mV})$ & & & 3330 \\
$\mathrm{X}(\mu \mathrm{S} / \mathrm{cm}$ & 4424 & & 4656 \\
$\mathrm{SO}_{4}^{2-}(\mathrm{mg} / \mathrm{l})$ & 3100 & & 812 \\
$\mathrm{Fe}(\mathrm{mg} / \mathrm{l})$ & 1130 & & 100 \\
$\% \mathrm{Fe}(\mathrm{II})$ & 100 & & 98 \\
$\mathrm{As}(\mathrm{mg} / \mathrm{I})$ & 205 & 348 & 81 \\
$\% \mathrm{As}(\mathrm{III})$ & 91 & 142 & \\
$\mathrm{Ca}{ }^{2+}(\mathrm{mg} / \mathrm{l})$ & & 11,8 & \\
$\mathrm{Mg}^{2+}(\mathrm{mg} / \mathrm{l})$ & & 27,6 & \\
$\mathrm{Cl}^{-}(\mathrm{mg} / \mathrm{l})$ & & 7,6 & \\
$\mathrm{~K}^{+}(\mathrm{mg} / \mathrm{l})$ & & & \\
$\mathrm{Na}^{+}(\mathrm{mg} / \mathrm{l})$ & &
\end{tabular}

(Johnson and Hallberg, 2005). Furthermore, As(III) is generally less efficiently removed than $\mathrm{As}(\mathrm{V})$ by adsorption or coprecipitation with iron minerals (Dixit and Hering, 2003); thus a better comprehension of the mechanisms favouring the trapping of this species under a stable solid phase would support the consideration of this phase for an application as a disposal material.

\section{Materials and experimental}

\subsection{Bacterial strains and culture conditions}

Experiments were performed with four different $A$. ferrooxidans strains known for their ability to oxidize iron and to potentially influence the nature of the mineral phase that precipitate. Three of them (B20, B5, CC1) were autochthonous, i.e. isolated from the Carnoulès AMD water, and one (ATCC 23270) was obtained from the American Type Culture Collection.

Strain B5 (accession number AJ879996) was chosen for this experiment because Morin et al. (2003) have evidenced, in a previous study, its ability to promote the formation of tooeleite after six days of cultivation in the Carnoulès AMD water. The isolation of $A$. ferrooxidans B5 strain was described previously in Bruneel et al. (2003). This strain was grown at $30{ }^{\circ} \mathrm{C}$ for 5 days and then at room temperature without shaking. The liquid culture medium was composed of $0.2 \%$ (wt/vol) $\mathrm{FeSO}_{4} .7 \mathrm{H}_{2} \mathrm{O}$ adjusted to $\mathrm{pH} 2.2$ with $\mathrm{H}_{2} \mathrm{SO}_{4}$ and sterilized by filtration, $0.5 \%$ (wt/vol) $\mathrm{Na}_{2} \mathrm{~S}_{2} \mathrm{O}_{3} .5 \mathrm{H}_{2} \mathrm{O}$ sterilized by filtration and $7 \%$ ( $\mathrm{vol} / \mathrm{vol}$ ) solution for basal salts containing $\left(\mathrm{NH}_{4}\right)_{2} \mathrm{SO}_{4}, 50 \mathrm{~g} \mathrm{l}^{-1} ; \mathrm{KCl}_{1} 1.66 \mathrm{~g} \mathrm{l}^{-1}$; $\mathrm{K}_{2} \mathrm{HPO}_{4}, 0.833 \mathrm{gl}^{-1} ; \mathrm{MgSO}_{4} .7 \mathrm{H}_{2} \mathrm{O}, 8.33 \mathrm{gl}^{-1} ; \mathrm{Ca}\left(\mathrm{NO}_{3}\right)_{2} .4 \mathrm{H}_{2} \mathrm{O}, 0.24 \mathrm{gl}^{-1}$ adjusted to $\mathrm{pH} 3.5$ with $\mathrm{H}_{2} \mathrm{SO}_{4}$ and autoclaved.

Strain B20 (accession number FM242697) was newly isolated for the present study using the same procedure than for strain B5 (see description above). It was chosen because preliminary incubation experiments in the Carnoulès AMD water revealed the presence of tooeleite in the precipitate.

Strains CC1 (accession number AJ457804) and ATCC 23270 (accession number AJ278718) were shown by Duquesne et al. (2003) to promote the formation of As(III)-bearing schwertmannite in a synthetic medium similar to the Carnoulès AMD water. The isolation of A. ferrooxidans CC1 was previously described by these authors. Strains ATCC 23270 and CC1 were grown at $30{ }^{\circ} \mathrm{C}$ with vigorous shaking in the liquid $\mathrm{Fe}(\mathrm{II})$ medium which consists of $3.5 \%$ (wt/vol) $\mathrm{FeSO}_{4} .7 \mathrm{H}_{2} \mathrm{O}$ adjusted to $\mathrm{pH} 2.2$ with $\mathrm{H}_{2} \mathrm{SO}_{4}$, and $25 \%$ (vol/vol) solution for basal salts containing $\left(\mathrm{NH}_{4}\right)_{2} \mathrm{SO}_{4}$, $0.4 \mathrm{~g} \mathrm{l}^{-1} ; \mathrm{K}_{2} \mathrm{HPO}_{4}, 0.4 \mathrm{~g} \mathrm{l}^{-1}, \mathrm{MgSO}_{4} .7 \mathrm{H}_{2} \mathrm{O}, 0.4 \mathrm{~g} \mathrm{l}^{-1}$, and trisodium citrate $\left(\mathrm{C}_{6} \mathrm{H}_{5} \mathrm{Na}_{3} \mathrm{O}_{7} .2 \mathrm{H}_{2} \mathrm{O}\right), 0.3 \mathrm{~g} \mathrm{l}^{-1}$, adjusted to $\mathrm{pH} 3$ with $\mathrm{H}_{2} \mathrm{SO}_{4}$.

\subsection{Bioassays and modelling}

Two series of bioassays were performed in the Carnoulès AMD water. The first one was designed to investigate the influence of the different bacterial strains on the nature of the As-bearing minerals that form during Fe(II) oxidation. Strains B5, B20, ATCC and CC1 were inoculated separately in the Carnoulès AMD water sampled in October $2004.5 \mathrm{ml}$ of suspension of pure A. ferrooxidans strain was inoculated in $500 \mathrm{ml}$ of filter-sterilized Carnoulès AMD water. A control experiment without bacteria was prepared by inoculation of $5 \mathrm{ml}$ of sterile culture medium in filtersterilized Carnoulès AMD water. This water contained $1130 \mathrm{mg} \mathrm{l}^{-1}$ of Fe, $3100 \mathrm{mg} \mathrm{l}^{-1}$ of sulphate, $205 \mathrm{mg} \mathrm{l}^{-1}$ of As (91\% of As(III)) and had a pH of 3.4 (Table 1). It was sterilized by filtering through $0.22 \mu \mathrm{m}$ pore size membranes.

The second bioassay was designed to investigate the influence of the initial bacterial cell concentration on the nature of the As-bearing minerals that form in the Carnoulès AMD water. Strain B5 was inoculated at concentrations of $0.4 \times 10^{6}, 1.2 \times 10^{6}$ and $4.8 \times 10^{6}$ cells $\mathrm{ml}^{-1}$ in the Carnoulès AMD water sampled in May 2007. The initial composition of the Carnoulès AMD water was $812 \mathrm{mg} \mathrm{l}^{-1}$ of $\mathrm{Fe}, 97.5 \mathrm{mg} \mathrm{l}^{-1}$ of As ( $81 \%$ of As (III)), $4656 \mathrm{mg} \mathrm{l}^{-1}$ of $\mathrm{SO}_{4}$ and the $\mathrm{pH}$ value was 3.2 (Table 1 ).

Reactors were covered with an aluminium cap in order to limit the evaporation and they were stored at $30^{\circ} \mathrm{C}$ and stirred continuously on an agitation table. All reactors were prepared in duplicates.

The program PHREEQC (Parkhurst and Appelo, 1999) coupled with the Thermoddem database (Blanc et al., 2007) has been used for the thermodynamic modelling of the second series of bioassays. Calculation of saturation indices have been done with solubility data from Yu et al. (1999).

\subsection{Chemical and mineralogical analyses}

An aliquot of $10 \mathrm{ml}$ of each solution was taken after 1, 2, 5, 9,16 and 30 days for the first bioassay and after 1, 3, 8, 10, 13, 17, 20, 23, 27, 36
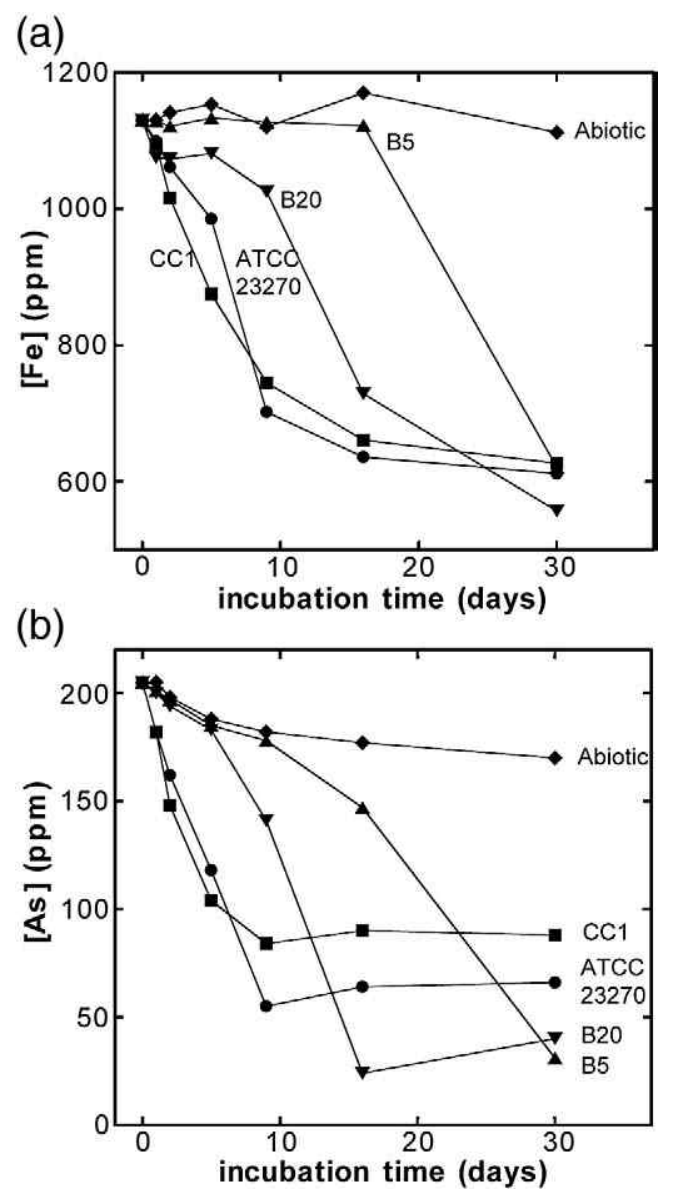

Fig. 1. Changes in Fe (a) and As (b) concentrations in the aqueous phase during experimental incubation of AMD water inoculated with various Acidithiobacillus ferrooxidans strains (first bioassay). The initial solution chemistry is: $1130 \mathrm{mg} \mathrm{l}^{-1} \mathrm{Fe}$, $3100 \mathrm{mg} \mathrm{l}^{-1} \mathrm{SO}_{4}^{2-}, 205 \mathrm{mg} \mathrm{l}^{-1}$ As (91\% As(III)), pH 3.4. 
(a)

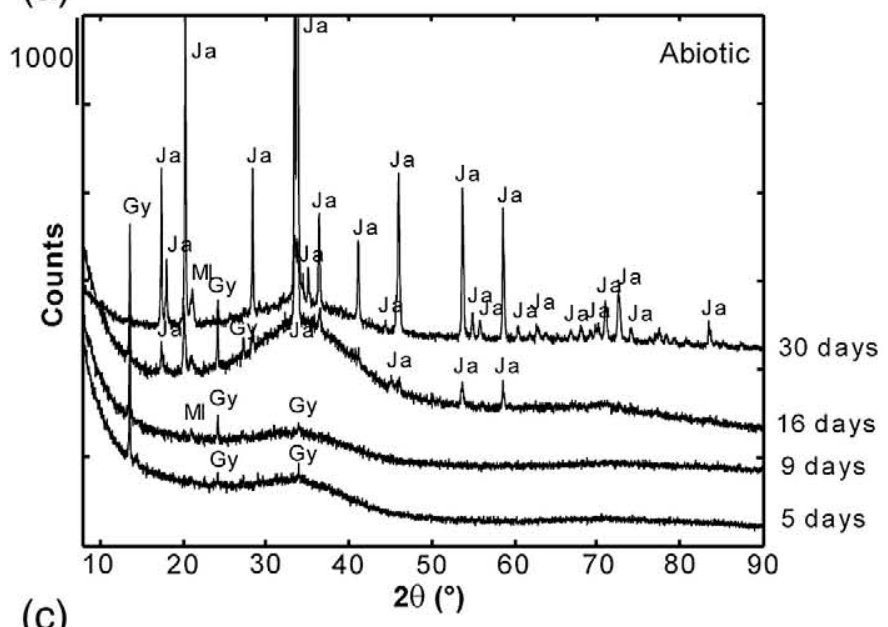

(c)

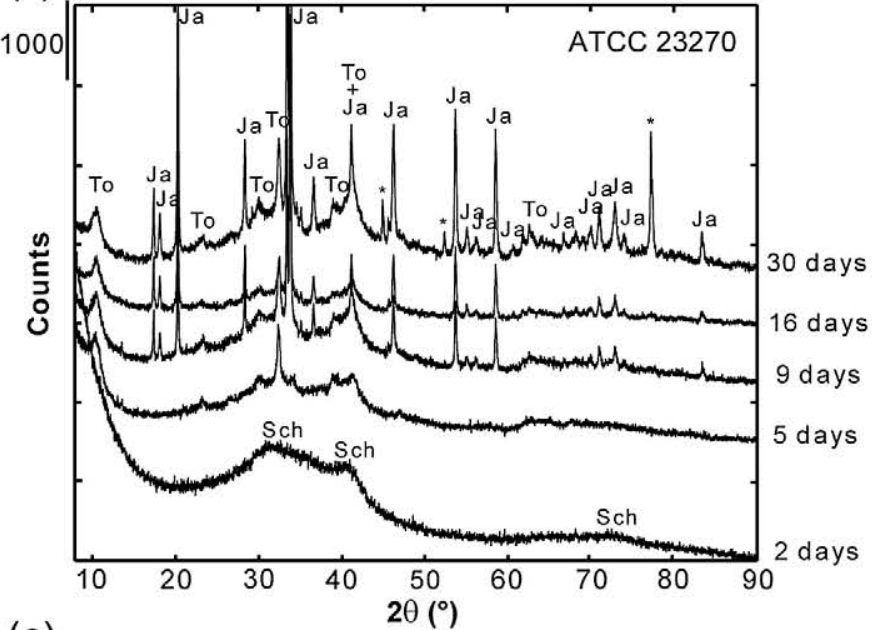

(e)

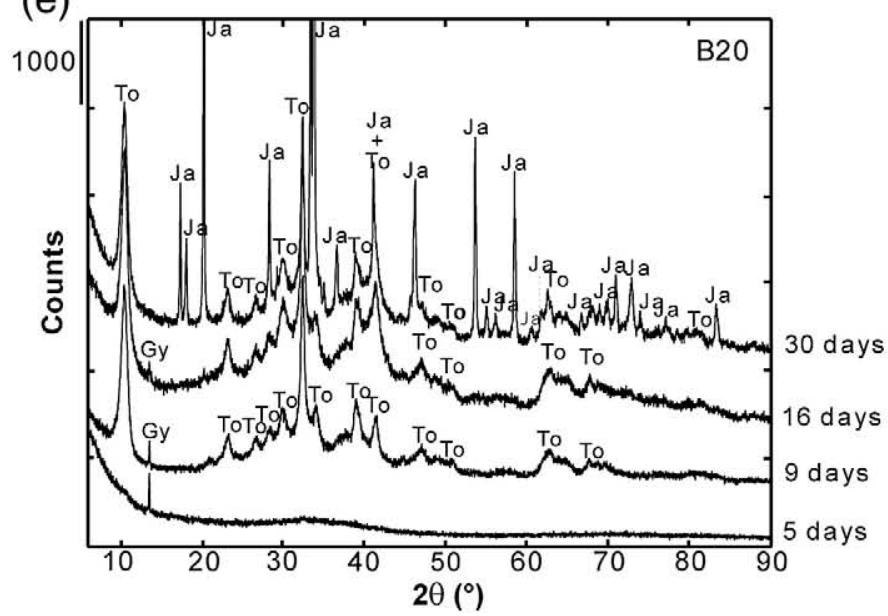

(b)

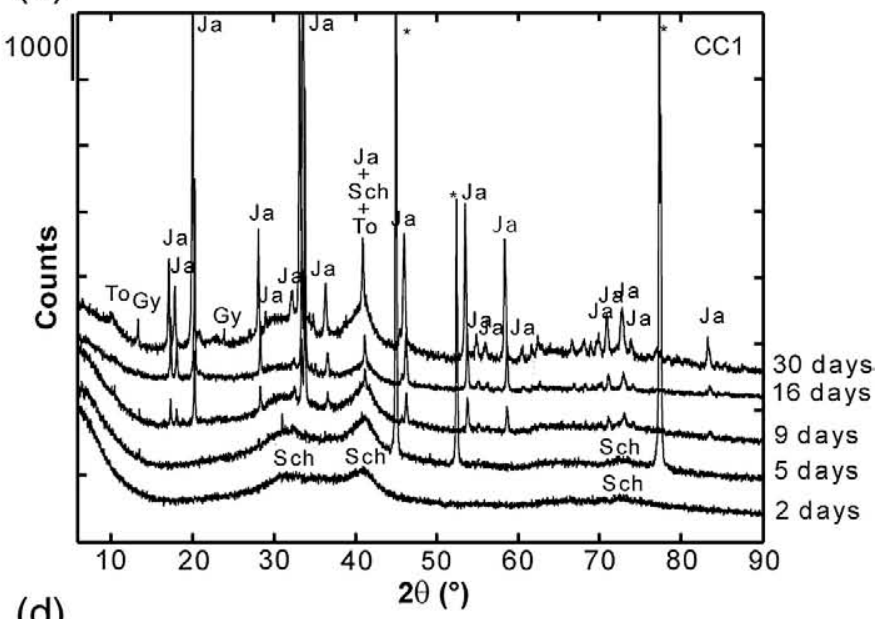

(d)

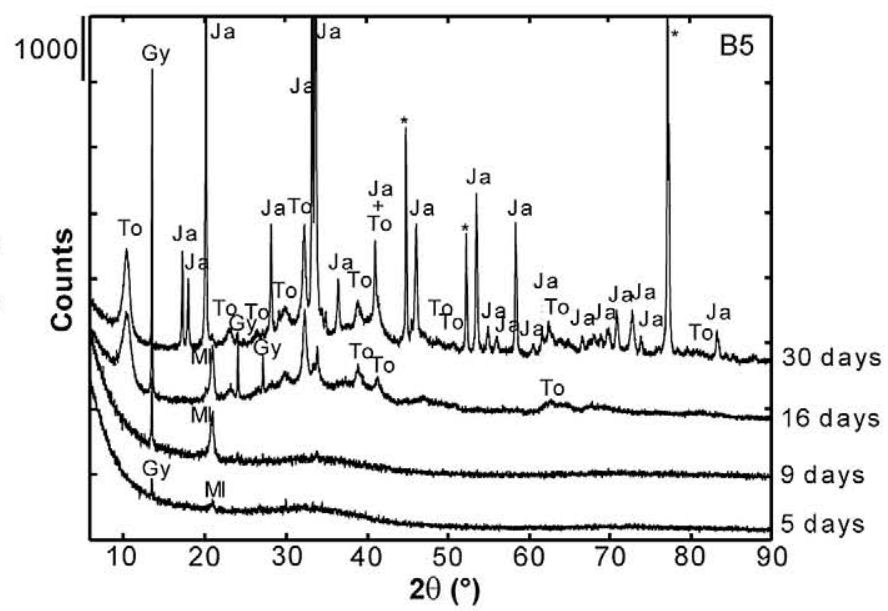

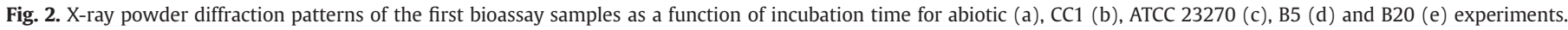
To: tooeleite; Ja: jarosite; Gy: gypsum; Ml: melanterite; Sch: schwertmannite.

and 44 days for the second bioassay. Each aliquot was centrifuged. The supernatant was filtered through $0.22 \mu \mathrm{m}$ disposable filter and syringe. In the first bioassay, total concentrations of $\mathrm{Fe}$, As and $\mathrm{SO}_{4}$ were determined. In the second bioassay, As species (As(III), As(V)), $\mathrm{Fe}(\mathrm{II})$, bacterial cells concentration and $\mathrm{pH}$ were also monitored.

Sulphate concentration was determined by nephelometry with a spectrophotometer at $650 \mathrm{~nm}$. The subsample taken for total As and total Fe determination was acidified $(1 / 1000 \mathrm{v} / \mathrm{v})$ with Suprapur
$\mathrm{HNO}_{3}$ (Merck). Iron and arsenic concentrations in the aqueous phase were determined by atomic absorption spectrometry (AAS) and Inductively Coupled Plasma Mass Spectrometry (ICP-MS) respectively. The subsample taken for Fe(II) determination was buffered with acetate and analyzed immediately after complexation with phenanthrolinum chloride solution using a spectrophotometer at the wavelength of $510 \mathrm{~nm}$. The subsample taken for As speciation was preserved with $0.0125 \mathrm{M}$ EDTA and analyzed within $24 \mathrm{~h}$. Arsenic 


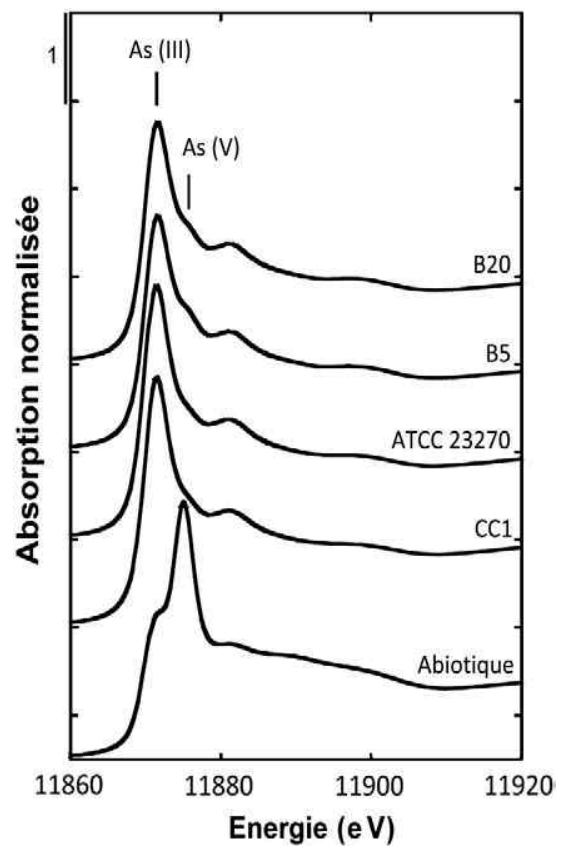

Fig. 3. XANES data of the solid samples from the first bioassay after 30 days of incubation.

speciation was carried out using HPLC coupled to Hydride Generation Atomic Fluorescence Spectrometry as described previously (Casiot et al., 2005). Bacterial cell concentration was determined by counting using Thoma cells. The $\mathrm{pH}$ was measured with an ultrameter CAMLAB equipped with pH/ORP Sensor Model RPR (Myron Company).

The solid recovered in the centrifugation vial was dried under vacuum to prevent oxidation. The mineralogical composition of the solid samples was determined by X-Ray powder diffraction (XRD) using Co $\mathrm{K} \alpha$ radiation. Data were recorded over a $2 \theta$ range of $3-85^{\circ}$ with a step size of $0.03^{\circ}$. The first bioassay samples were analyzed using a Phillips PW1710 diffractometer equipped with a graphite backmounted monochromator, counting 6 to 80 s per step depending on the sample amount. The second bioassay samples were analyzed in continuous mode using a Panalytical X'Pert Pro MPD diffractometer equipped with an X'Celerator detector, counting $2 \mathrm{~h}$ per sample.

X-ray absorption spectra were collected on the bioassay samples at the As K-edge over the energy range $11,630-12,630 \mathrm{eV}$ on the wiggler beamline 11-2 at the Stanford Synchrotron Radiation Laboratory (SSRL, Stanford, California, USA). Energy was calibrated with scorodite $\left(\mathrm{FeAs}^{\mathrm{V}} \mathrm{O}_{4} \cdot 2 \mathrm{H}_{2} \mathrm{O}\right)$, placed after the second ion chamber, with the maximum absorption point chosen to be $11,875 \mathrm{eV}$, thus yielding a maximum absorption position at $11,871.3$ for As(III) (Morin et al., 2003; Ona-Nguema et al., 2005). EXAFS data were extracted using the XAFS program (Winterer, 1997) following the procedure detailed previously (Ona-Nguema et al., 2005). Unfiltered $k^{3}$-weighted EXAFS data of bioassay samples were least squares fit using a LevenbergerMarquard minimization procedure, by linear combination of EXAFS spectra selected among a large set of model compounds data collected at $10 \mathrm{~K}$. Fit quality was estimated using a residual factor of the following form: $R_{\mathrm{f}}=\sum\left(k^{3} \chi(k)_{\exp }-k^{3} \chi(k)_{\text {calculated }}\right)^{2} /\left(k^{3} \chi(k)_{\exp }\right)^{2}$. A Debye-Waller term $\sigma\left(\hat{\mathrm{A}}^{2}\right)$ was also fitted in order to adjust the RT data on the bioassay samples to the $10 \mathrm{~K}$ model compounds data. Fourier transforms of the experimental and calculated spectra were performed within the 3-14 $\AA^{-1} k$-range, using a Kaiser-Bessel windowing and a Bessel parameter of 2.5. Our set of model compounds available for this fitting procedure included As(III)- and $\mathrm{As}(\mathrm{V})$-sorbed or coprecipitated schwertmannite and ferrihydrite samples with As/Fe molar ratio varying within the 0.09 to 0.8 range, obtained from biotic and abiotic experiments (Lebrun, 2005). This set especially includes the CC1 - 5 days sample corresponding to As(III)coprecipitated schwertmannite $\left(\mathrm{As} / \mathrm{Fe}=0.3 \mathrm{~mol} \mathrm{~mol}^{-1}\right)$, and also includes the well crystallized Utah tooeleite sample (Cesbron and Williams, 1992; Morin et al., 2007). All model compounds spectra were recorded at a temperature of $10 \mathrm{~K}$ using liquid He cryostat at the bending-magnet beamline BM30B (FAME) at the European Synchrotron Radiation Facility (ESRF, Grenoble, France) or on the D44 beamline at the LURE synchrotron (Orsay). All beamlines were equipped with $\mathrm{Si}(220)$ double-crystal monochromators, except on D44 where $\mathrm{Si}(111)$ crystals were used. EXAFS data were acquired in transmission mode after sample dilution in appropriate amounts of cellulose for As/Fe molar ratio above 0.2, and in fluorescence detection mode using CANBERRA Ge-30 elements array detector for lower arsenic concentrations (Lebrun, 2005).

\section{Results}

3.1. Removal of iron and arsenic by the various A. ferrooxidans strains studied

In the first bioassay, the concentration of dissolved Fe and As decreased dramatically at the beginning of the incubation for strains CC1 and ATCC 23270, showing that arsenic and iron simultaneously precipitated (Fig. 1). After ten days, arsenic precipitation stopped and iron precipitation slowed down. In the same bioassay (Fig. 1), for strains B5 and B20, Fe and As concentrations decreased slightly at the beginning of the incubation and decreased markedly after a lag time of nine days for B20 and sixteen days for B5. Corresponding first order Fe precipitation rate constants $\left(-0.050\right.$ and -0.043 day $^{-1}$ respectively) were similar than in the early CC1 $\left(-0.048\right.$ day $\left.^{-1}\right)$ and ATCC 23270 $\left(-0.046\right.$ day $\left.^{-1}\right)$ incubation experiments. Total iron remaining in solution at the end of the experiment was quite similar whatever the inoculated strain. Conversely, the amount of arsenic remaining in solution after thirty days varied markedly from one strain to another; strains B5 and B20 appeared to be the most efficient to remove arsenic. Comparatively, the control experiment showed little decrease of iron concentration after 30 days while As concentration decreased by $15 \%$.

\subsection{Mineralogy of the solid phases}

In the control experiment (Fig. 2a), the solid phase that formed during the first nine days was mainly amorphous. Traces of gypsum and melanterite were also detected. Jarosite appeared after 16 days. With strains CC1 (Fig. 2b) and ATCC 23270 (Fig. 2c), the solid phase that first precipitated was poorly ordered schwertmannite with As/Fe molar ratio of 0.3 and 0.5 respectively (calculated from Fig. 1 data). XRD peaks characteristic of tooeleite appeared after 5 days for ATCC 23270 and were not visible in the diffractograms of strain CC1 before 30 days. The crystallization of jarosite began after nine days for both strains. With strains B20 or B5 (Fig. 2d and e), an amorphous phase precipitated during the lag period. Tooeleite formed after nine days and sixteen days respectively. Jarosite was present for both strains in the late precipitate.

Finally, B5 and B20 clearly promoted the formation of tooeleite while CC1 promoted the formation of poorly-ordered schwertmannite. ATCC 23270 exhibited an intermediate behaviour and promoted the precipitation of both schwertmannite and tooeleite.

\subsection{Arsenic speciation and distribution in the solid phases}

The redox sate of arsenic and its distribution among the mineral species identified by XRD (Fig. 2) was determined using X-ray absorption spectroscopy analysis of the first bioassay samples after 30 days of incubation. XANES data (Fig. 3) indicated that arsenic is dominantly present as As(III) in the biotic samples, and as a mixture of 
(a)

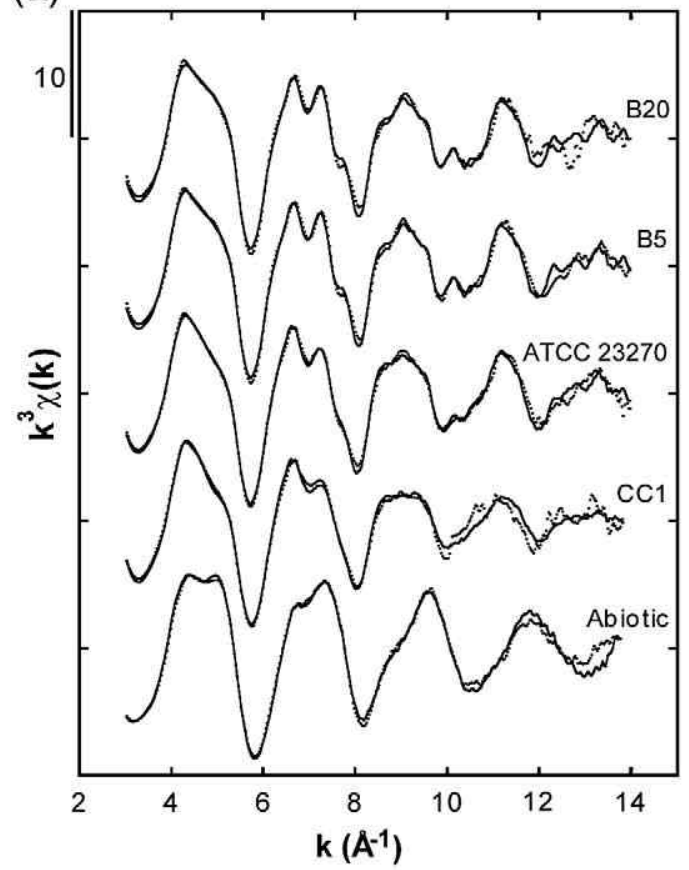

(c)

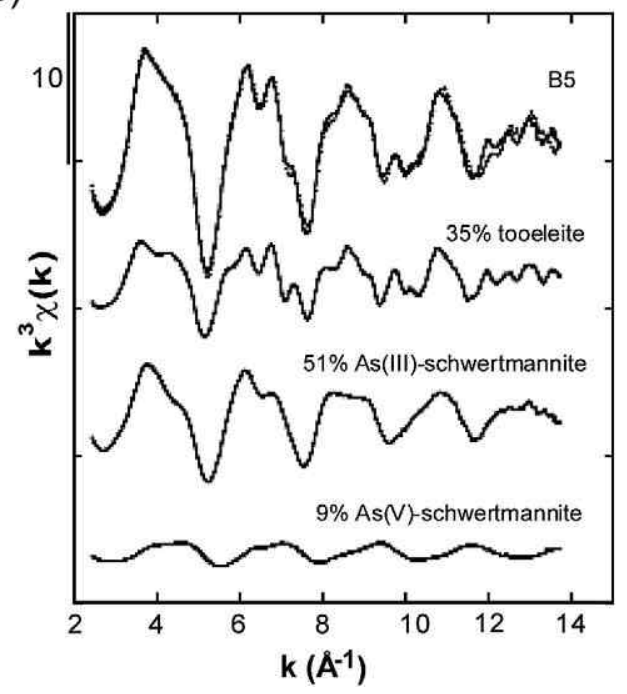

(b)

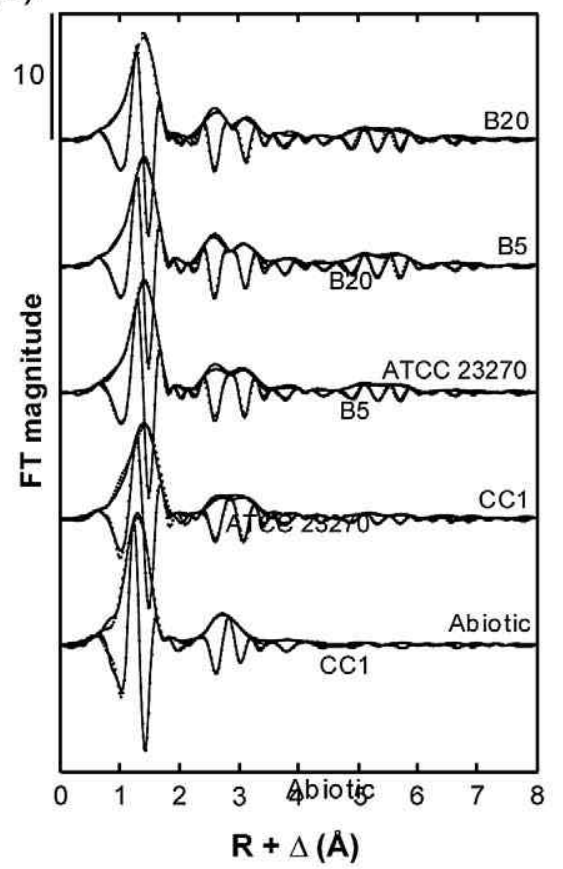

(d)

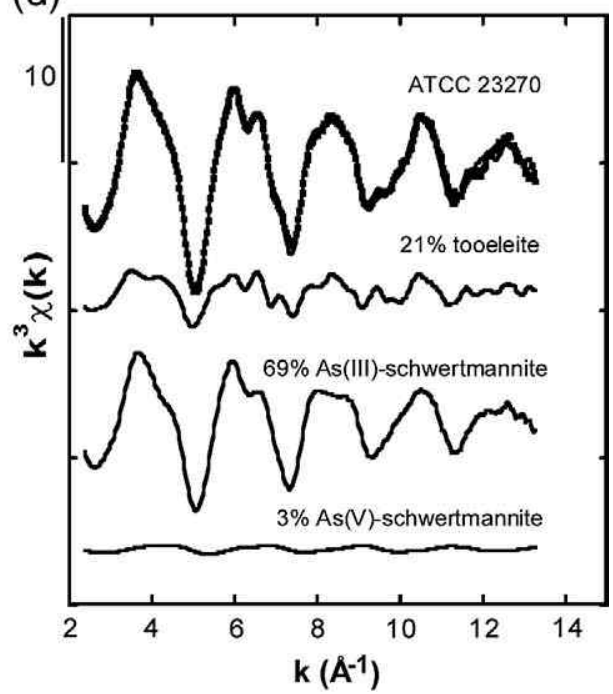

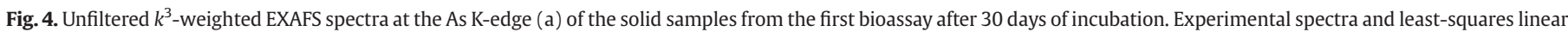

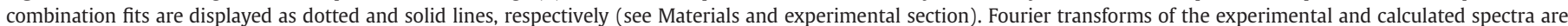
shown for comparison (b). An example of linear combination with model compounds spectra is also displayed below for B5 (c) and ATCC 23270 (d) samples after 30 days.

$\mathrm{As}(\mathrm{III})$ and $\mathrm{As}(\mathrm{V})$ in the abiotic control sample. These results indicate that As(III) which was the predominant form (91\%) of arsenic in the inoculated AMD water did not significantly oxidize during the biotic precipitation process. In contrast the presence of a large fraction of $\mathrm{As}(\mathrm{V})$ in the abiotic control sample indicates that, although the total amount of precipitated arsenic in this experiment is much lower than in the biotic ones, $\operatorname{As}(\mathrm{V})$ was preferentially incorporated in the abiotic precipitate.

EXAFS spectra of B5 and B20 samples are close to that of tooeleite, while the spectra of ATCC 23270 and CC1 samples are less structured (Fig. 4). Accordingly, best fits were obtained with linear combination of the spectra of As(III)-coprecipitated schwertmannite sample ( $\mathrm{CC} 1-5$ days; As $/ \mathrm{Fe}=0.3 \mathrm{~mol} \mathrm{~mol}^{-1}$ ), Utah tooeleite, and an $\mathrm{As}(\mathrm{V})$-component (Table 2; Fig. 4c). This fitting procedure indicated that the proportion of arsenic present as As(III)-coprecipitated schwertmannite increases from $49 \%$ for sample B20 to $89 \%$ for sample $\mathrm{CC} 1$, while the proportion of arsenic present as $\mathrm{As}(\mathrm{III})$ in tooeleite decreases from $36 \%$ in sample B20 to $6 \%$ in sample CC1. Actually, the exact nature of the non-tooeleite As(III) component could not be unequivocally determined from such an EXAFS fitting procedure, because EXAFS spectra of As(III)-coprecipitated, -sorbed schwertmannite and ferrihydrite samples exhibit strong similarities (Lebrun, 2005). However the As(III)-coprecipitated schwertmannite component in the present fit is in agreement with the dominant presence of schwertmannite in association with tooeleite in the samples studied, as determined by XRD.

The proportion of the $\mathrm{As}(\mathrm{V})$-component did not exceed $10 \%$ in all biotic samples of the first bioassay that were studied by EXAFS, in agreement with XANES data, which indicate that $\mathrm{As}(\mathrm{V})$ is minor in these samples (Fig. 3). Consequently, the nature of this $\mathrm{As}(\mathrm{V})$ component could not be reliably determined from the fitting of the biotic samples, and several $\mathrm{As}(\mathrm{V})$-sorption and coprecipitation model compounds spectra yield acceptable fits with similar $R_{\mathrm{f}}$ values. The 
Table 2

Arsenic spéciation in the solids sampled after 30 days of incubation, as determined by linear least-square fitting of their room temperature (RT) EXAF5 spectra, using experimental data Sum three relevant model compounds (see Materials and experimental section): i) Utah tooeleite $\mathrm{Fe}_{;}\left(\mathrm{Ns} \mathrm{O}, \mathbf{I}_{\Lambda} \mathrm{SO} . \mathbf{j} \mathbf{i} \bigcirc \mathbf{H} \mathbf{i}\right.$ i) poorly ordered $\mathrm{As}$ (III) schwertmannite corresponding to sample $\mathrm{CCl}$ after 5 days of incubation (As/Fe $=0.3 \mathrm{~mol} / \mathrm{mol})$ : and iii) synthetic $A s(V)$ sorbed schwertmannite $(A s / F e=0.09 \mathrm{~mol} / \mathrm{mol})$.

\begin{tabular}{|c|c|c|c|}
\hline \multirow[t]{2}{*}{ Sample } & $\begin{array}{l}\text { As (III) } \\
\text { tooeleite }\end{array}$ & $\begin{array}{l}\text { As (Ili)-coprecipitated } \\
\text { schwertmannite }\end{array}$ & $\begin{array}{l}\text { As }(V) \text { sorbed } \\
\text { schwertmannite }\end{array}$ \\
\hline & $(\%)$ & $(\%)$ & $(\%)$ \\
\hline $\mathrm{B} 20$ & 36 & 49 & 10 \\
\hline B5 & 35 & 51 & 9 \\
\hline 23270 & 21 & 69 & 3 \\
\hline $\mathrm{CCl}$ & 6 & 89 & 8 \\
\hline Abiotic & 0 & 32 & 58 \\
\hline
\end{tabular}

Fit quality was estimated using a residual factor of the following form: $R f=$ $\left.f\left(k^{3} /(k)_{\text {cxp }}-k M k\right)_{c \text { sicuistcd }}\right)^{2} /\left(I f^{3} /(k)_{\text {cxp }}\right)^{2}$. A Debye-Waller term $<t\left(A^{2}\right)$ was also fitted in order to adjust the RT data on the bioassay samples to the $10 \mathrm{~K}$ model compounds data. Estimated standard deviation on the fitted components is $10 \%$ and components below $5 \%$ are not significant.

choice of the $\mathrm{As}(\mathrm{V})$ component was based on the fit of the control sample spectrum, for which the best fits were obtained by combining a dominant $(-60 \%)$ component of As(V)-sorbed (or coprecipitated) schwertmannite (with As/Fe molar ratio -0.1), to a minor As(III)component that could not be unequivocally determined (Fig. 4; Table 2). It is known from previous studies on $\mathrm{As}(\mathrm{V})$-doped schwertmannite (Waychunas et al., 1995) and ferrihydrite (Waychunas et al., 1993; Cancès et al., 2005, 2008; Paktunc et al., 2008) that, more than the preparation method (coprecipitation or sorption), the increase of the As/Fe ratio influences the shape of the As-EXAFS spectrum of such compounds. Indeed, these studies reported that the amplitude of the As-Fe pair contributions increases as the As/Fe ratio increases. In the present study, we observed that $\mathrm{As}(\mathrm{V})$-sorbed (or coprecipitated) schwertmannite with $\mathrm{As} / \mathrm{Fe}=0.09$ better match the control sample than sorption or coprecipitation compounds with As/Fe ratio higher than 0.1 (Cancès et al,, 2005; Lebrun, 2005; Cancès et al., 2008).

\subsection{Influence of bacterial cell concentration on mineral formation}

Owing to the differences observed between the results obtained with the various strains in the first bioassay, we hypothesized that bacterial cell concentration may control the mineralogy of biogenic $\mathrm{Fe}$ (III) products. In the second bioassay, when B5 strain was inoculated at concentration levels of $0.4 \times 10^{\mathrm{S}}, 1.2 \times 106$ and $4.8 \times 106$ cells $\mathrm{ml}^{*}{ }^{* 1}$, the lag period decreased from 10 to 3 days (Fig. 5a). This lag phase duration was shorter than in the first series of bioassays carried out with strain B5 whose initial cell concentration (not determined) was probably lower. After the lag phase, Fe(II) concentration decreased drastically and $\mathrm{Fe}$ (II) oxidation reached completion after 13 to 20 days (Fig. 5a). Fig. 5b shows the increase of the number of $A$. ferrooxidans cells as a function of time. These growth curves confirmed that $A$. ferrooxidans was in exponential growth phase between 10 and 20 days. Flowever, it should be noted that the microbial viable counts are only representative of microorganisms in suspension, and not of those attached to surfaces of precipitates or glass, leading to cell concentrations that were largely underestimated as observed in the study of Yu et al. (2001). This bias may explain why no significant difference in cell counts is observed between the $0.4 \times 10^{\mathrm{s}}, 1.2 \times 106$
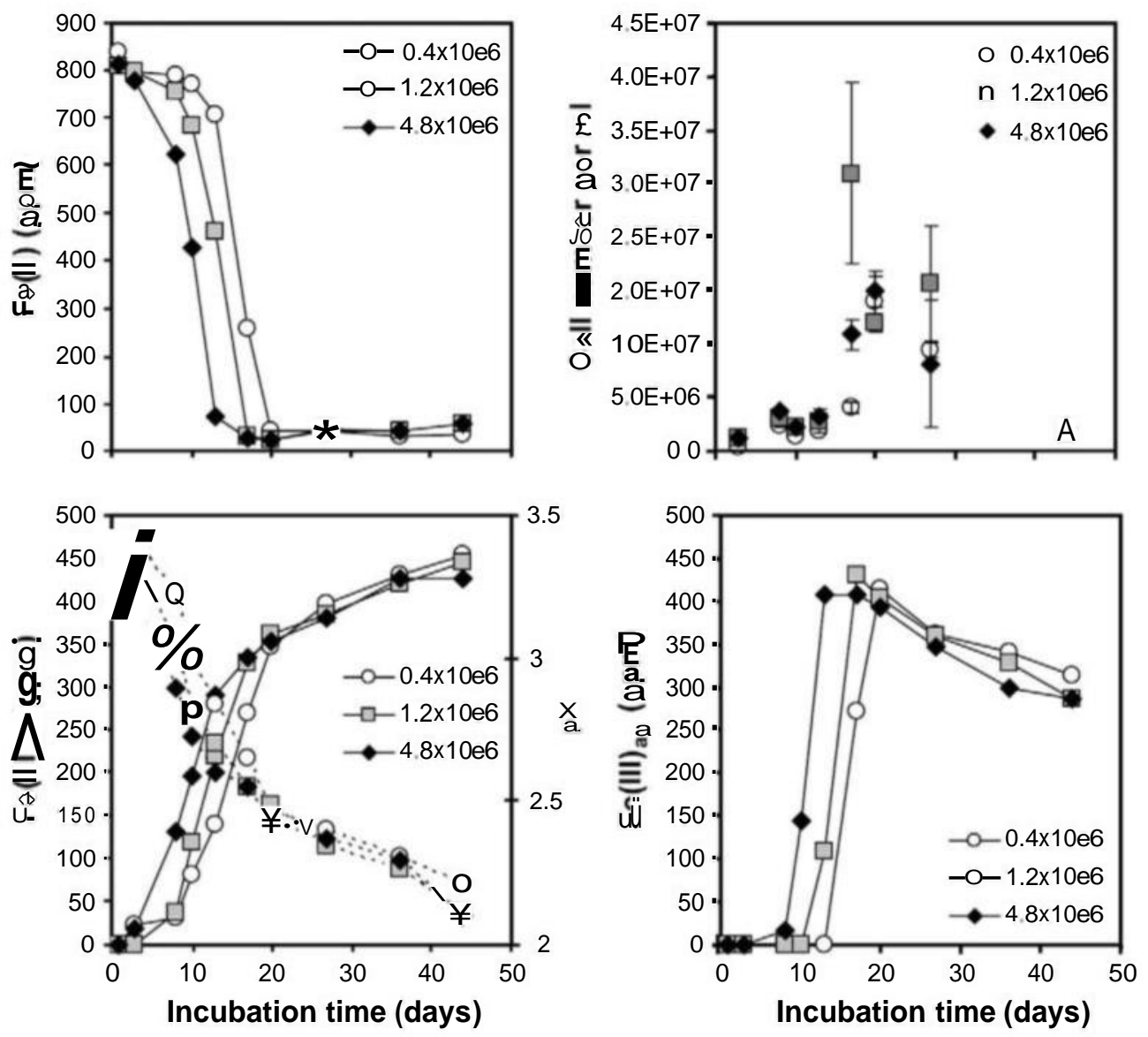

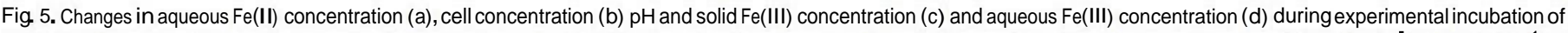

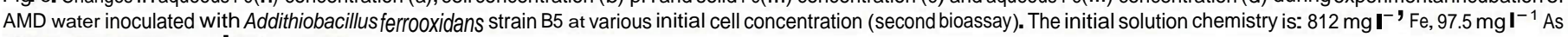
(81\% As(III)), 4656 $\mathrm{mgl}^{-1}$ sol- ${ }^{-}, \mathrm{pH} 32$. 

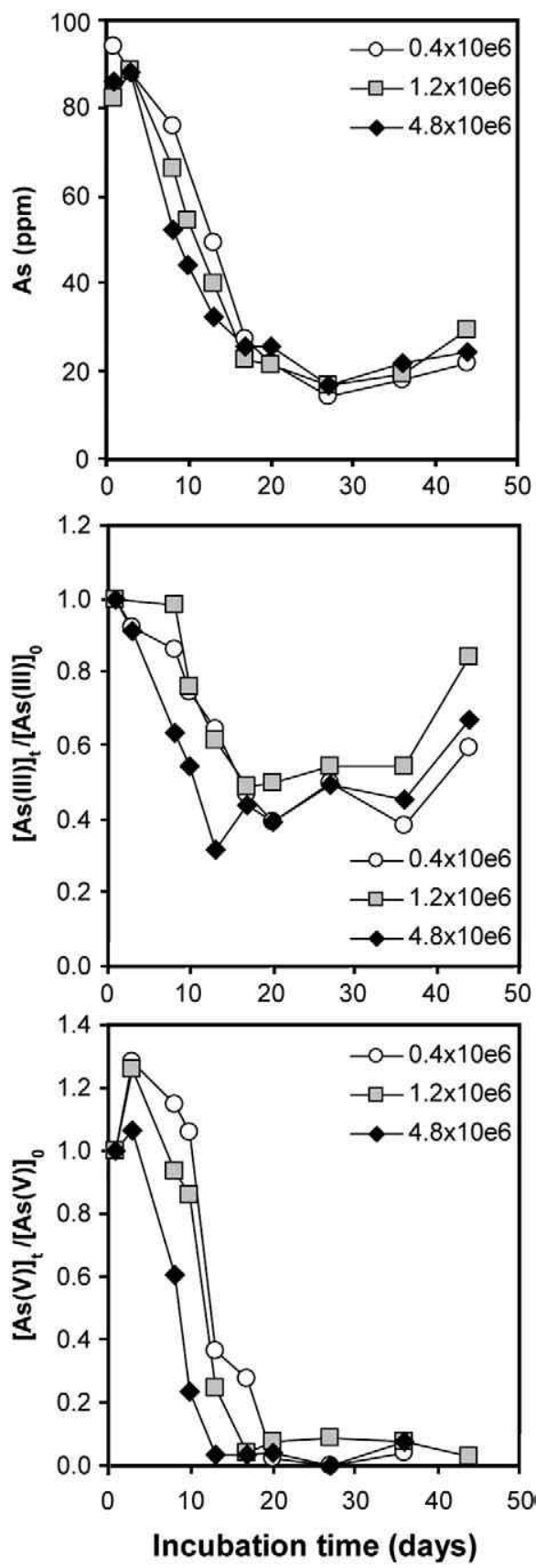

Fig. 6. Changes in total As concentration (a) and ratio of $\mathrm{As}(\mathrm{III})$ (b) and $\mathrm{As}(\mathrm{V})$ (c) concentrations at the incubation time (suffix " $t$ ") to their initial concentration (suffix " 0 ") during experimental incubation of AMD water inoculated with Acidithiobacillus ferrooxidans strain B5 at various initial cell concentration (second bioassay).

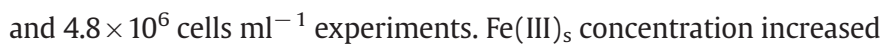
in the early stage of $\mathrm{Fe}(\mathrm{II})$ oxidation (Fig. $5 \mathrm{c}$ ) while $\mathrm{Fe}(\mathrm{III})_{\text {aq }}$ appeared 8 to 13 days later (Fig. 5d). The rate of Fe precipitation during exponential growth phase was similar for the three cell concentration levels and averaged $-0.046 \pm 0.003$ day $^{-1}$, similarly to the rate in the first series of bioassays. After exponential growth phase, cell concentration decreased (Fig. 5b) but $\mathrm{Fe}(\mathrm{III})_{\mathrm{s}}$ concentration still increased in relation with a decrease of $\mathrm{Fe}(\mathrm{III})_{\mathrm{aq}}$. The $\mathrm{pH}$ decreased from $3.26 \pm 0.06$ to $2.14 \pm 0.06$ in relation with the precipitation of Fe (III) $)_{\mathrm{s}}$ (dotted lines Fig. 5c).

Arsenic concentration decreased markedly in the first 15 days of incubation (Fig. 6a), corresponding to the end of the lag period for Fe (II) oxidation. Both $\mathrm{As}(\mathrm{III})$ and $\mathrm{As}(\mathrm{V})$ concentrations decreased (Fig. 6b and c); however, $\mathrm{As}(\mathrm{V})$ was removed more efficiently than
As(III) since residual concentrations remaining in solution after 20 days represented less than $10 \%$ of initial concentration for $\mathrm{As}(\mathrm{V})$ and about $50 \%$ for $\mathrm{As}(\mathrm{III})$. Moreover, As(III) concentrations in the dissolved phase rose again after 20 days (Fig. 6b).

According to thermodynamic data reported in Yu et al. (1999), the modelling of our experiments with PHREEQC (Parkhurst and Appelo, 1999) showed that the water reached supersaturation with respect to schwertmannite and jarosite (Fig. 7) as soon as significant concentrations of $\mathrm{Fe}^{3+}\left(\geq 50 \mathrm{mg} \mathrm{l}^{-1}\right)$ appeared in solution and oversaturation was maintained in the first 36 days of incubation whatever initial cell concentration. Supersaturation towards schwertmannite was higher than towards jarosite during the first 36 days of incubation; thus the precipitation of schwertmannite was more thermodynamically favourable. After 36 days, the saturation indices of jarosite became higher than that of schwertmannite, which assumed the precipitation of jarosite rather than schwertmannite in the late days of incubation. These thermodynamic predictions are in agreement with our mineralogical data from $1.2 \times 10^{6}$ to $4.8 \times 10^{6}$ experiments, which indicate that both phases formed in these experiments (Fig. 8). Indeed, schwertmannite formed after 20 days of incubation and jarosite appeared after extended incubation ( $\geq 36$ days). XRD peaks characteristic of tooeleite were also present but this mineral was less abundant than in the first bioassay (Fig. 8a). Furthermore, after a 20 day incubation, tooeleite was less abundant in the $4.8 \times 10^{6}$ cells $\mathrm{ml}^{-1}$ experiment than in the $1.2 \times 10^{6}$ cells $\mathrm{ml}^{-1}$ one (Fig. $8 \mathrm{a}$ ). This result agreed with previous observations from the first bioassay which lead to invoke a kinetic factor in the formation of tooeleite.

\section{Discussion}

4.1. Mechanism of formation of tooeleite, As-rich schwertmannite and jarosite

We observed in a previous study (Morin et al., 2003) that aging of As(III)-rich Carnoulès AMD water inoculated with bacterial strain B5 lead to the precipitation of tooeleite after 6 days incubation whereas another A. ferrooxidans strain B4 did not lead to tooeleite formation. In the present experiments, we demonstrated that the formation of tooeleite was not inferred only to strain B5. The formation of this mineral also occurred when the Carnoulès AMD water was inoculated with two other strains CC1 and B20 originating from this As-rich mining site but also with a collection strain, ATCC 23270. Thus, the formation of tooeleite was not related to a phenotypic peculiarity of strain B5 or to A. ferrooxidans strains originating from the Carnoulès mining site. However, the nature, proportion and sequence of the mineral forming during the incubation period differed from one strain to another. Tooeleite appeared sooner in experiments with strains B5 and B20 and represented the major As-bearing mineral in the final precipitate. The formation of this phase appeared to be favoured during extended lag period during which Fe(II) was slightly oxidized but at slower rate than during exponential growth phase. Conversely, when the lag phase was extremely short, in experiments with strains CC1 and ATCC 23270, the first mineral phase that formed in the early stage of Fe precipitation was As(III)-rich schwertmannite and this mineral was predominant in the final precipitate. Thus, Fe(II) oxidation rate appeared to control the relative amounts of tooeleite and schwertmannite forming in our biotic experiments. This was confirmed in the second series of bioassays where increased cell concentration lead to shorter lag period and lower amount of tooeleite relatively to schwertmannite after 20 day incubation. Such influence of microbial $\mathrm{Fe}(\mathrm{II})$ oxidation rate on the mineralogy of the $\mathrm{Fe}(\mathrm{III})$ biominerals was for instance observed by Senko et al. (2005) in nitrate-dependent $\mathrm{Fe}(\mathrm{II})$ oxidation experiments at neutral $\mathrm{pH}$. These authors demonstrated that when $\mathrm{Fe}(\mathrm{II})$ oxidation rates slowed, a stronger goethite signal was observed by XRD and a larger proportion of $\mathrm{Fe}(\mathrm{III})$ was in the crystalline fraction. 


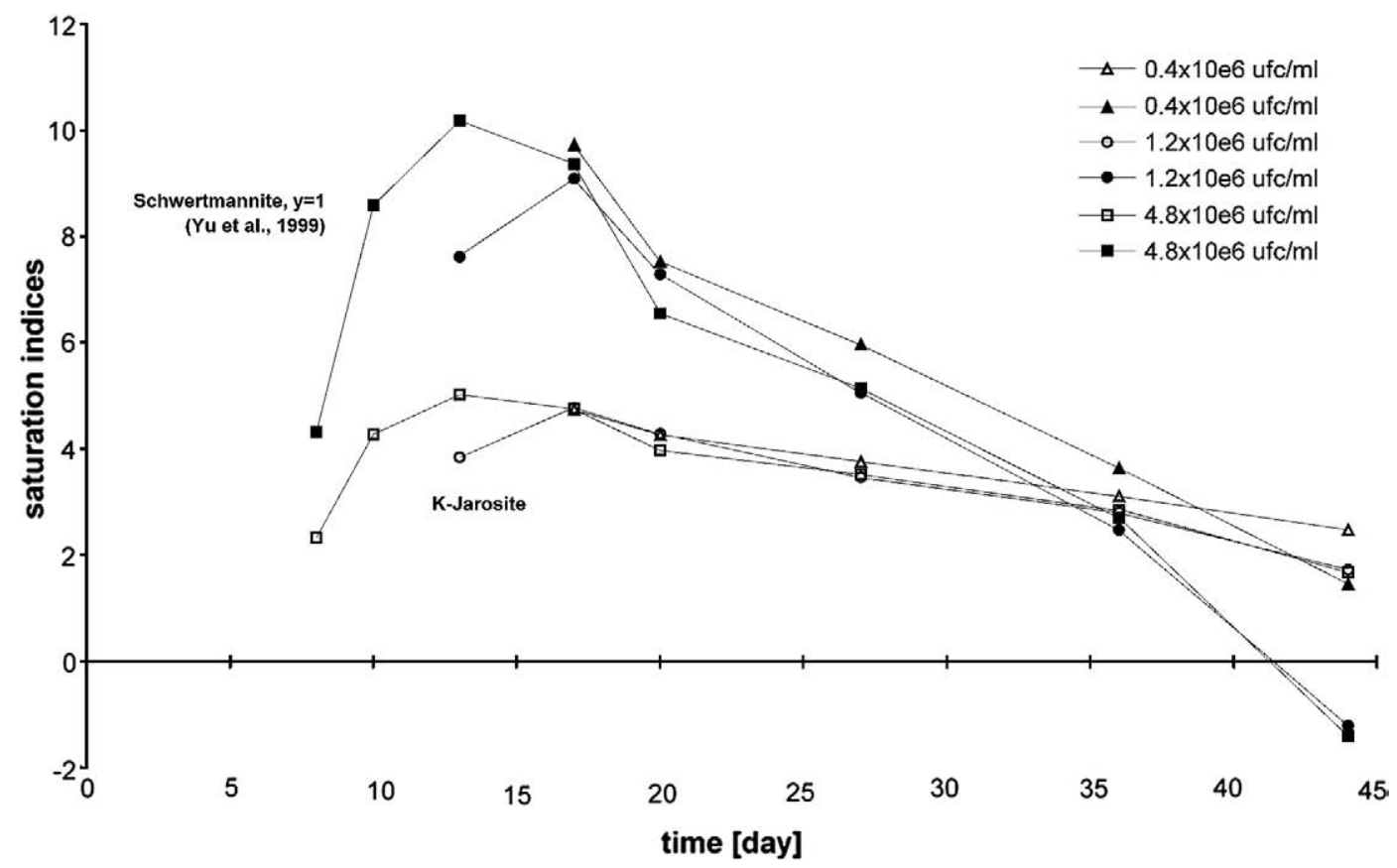

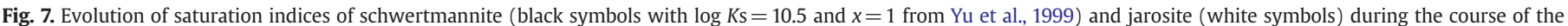
experiments, which have been calculated according to PHREEQC modelling (Parkhurst and Appelo, 1999).

The pattern of the curves representing the amount of As versus Fe removed for each strain exhibited a similar slope in the early stage of Fe precipitation for strains ATCC 23270, CC1 and B20, which corresponded to an arsenic retention yield of $0.44 \pm 0.08 \mathrm{~mol}_{\mathrm{As}}$ $\mathrm{mol}_{\mathrm{Fe}}^{-1}$ (Fig. 9). Such As/Fe ratio in the precipitate reflected the contribution of tooeleite with As/Fe ratio of 0.67 (Morin et al., 2007) and As(III)-schwertmannite, whose As/Fe ratio was 0.3-0.5; these ratios were determined from the early (2-5 days) CC1 and ATCC 23270 precipitates which only contained schwertmannite as evidenced by XRD spectra. Such arsenic load in schwertmannite should have disrupted the crystallisation of this mineral according to Carlson et al. (2002). Indeed, these authors found that schwertmannite precipitated from $\mathrm{As}(\mathrm{V})$-rich $\mathrm{AMD}$ was replaced by an amorphous phase at high $\mathrm{As}(\mathrm{V})$ levels corresponding to As/Fe mole ratios higher than 0.15 . The persistence of disordered and nanocrystalline schwertmannite at such high arsenic loading in our experiments is likely related to the fact that arsenic is present as $\mathrm{As}(\mathrm{III})$ and not as $\mathrm{As}(\mathrm{V})$ as it was the case in the study of Carlson et al. (2002). It may thus be inferred that the poisoning role of $\mathrm{As}(\mathrm{III})$ for schwertmannite formation is less pronounced than that of $\mathrm{As}(\mathrm{V})$. Further study of the detailed nature of the As(III)-schwertmannite interactions at the molecular level would be needed to confirm this hypothesis.

Slow abiotic Fe(II) oxidation in our control experiment did not lead to the formation of tooeleite but to an amorphous phase. That may be explained by an undersaturation with respect to tooeleite because Fe (II) oxidized very slowly in acidic conditions without bacteria. Indeed, the solubility product of tooeleite (formulated as $\mathrm{Fe}_{6}\left(\mathrm{AsO}_{3}\right)_{4} \mathrm{SO}_{4}$ $(\mathrm{OH})_{4} \cdot 4 \mathrm{H}_{2} \mathrm{O}$ by Morin et al., 2007) was estimated to $\log K \approx 23$ from dissolved Fe and As concentrations measured at the end of synthesis experiments carried out by Nishimura and Robins (2008); this value suggests that this phase is more soluble than schwertmannite (log $K=10.5$ from Yu et al., 1999); $\log K=18$ from Bigham et al., 1996) and amorphous ferric arsenate phases ( $\log K=-23$ according to Langmuir et al., 2006). From this solubility product value it appears that the $\mathrm{Fe}(\mathrm{III})$ concentration required to reach the saturation with respect to tooeleite in the Carnoulès water that contain $187 \mathrm{mg} \mathrm{l}^{-1}$ of $\mathrm{As}(\mathrm{III})$ is $\sim 30 \mathrm{mg} \mathrm{l}^{-1}$, whereas the concentration of $\mathrm{Fe}(\mathrm{III})$ in the abiotic experiment reached only $10 \mathrm{mg} \mathrm{l}^{-1}$ after 30 days. Thus, the amount of $\mathrm{Fe}$ (III) produced by abiotic oxidation is probably too low to initiate the precipitation of tooeleite, whereas it is probably sufficient to reach oversaturation with respect to $\mathrm{As}(\mathrm{V})$-rich $\mathrm{Fe}(\mathrm{III})$ precipitate. Such precipitation would scavenge Fe(III) as soon as it is produced and would hinder the oversaturation to increase enough to initiate the precipitation of tooeleite. Thus, saturation relatively to tooeleite appears to be only reached via active microbial oxidation of $\mathrm{Fe}(\mathrm{II})$ in our experimental conditions. Consequently, although the role of bacterial surfaces in the crystallisation of minerals has been documented in several studies (Fortin et al., 1998; Warren and Ferris, 1998; Kasama and Murakami, 2001; Jones and Renaut, 2007), it is not necessary to invoke such processes to explain the specific formation of tooeleite in our biotic experiments and not in the abiotic control. Indeed, Nishimura and Robins (2008) recently synthesized tooeleite via abiotic pathway at room temperature using $\mathrm{Fe}(\mathrm{III})$ and $\mathrm{As}$ (III) initial concentration of 5.6 and $7.5 \mathrm{~g} \mathrm{l}^{-1}$ respectively.

From the solubility product of schwertmannite $(\log K=10.5$, Yu et al., 1999), it appears that the $\mathrm{Fe}$ (III) concentration required to reach the saturation with respect to this mineral in the Carnoulès water is $0.016 \mathrm{mg} \mathrm{l}^{-1}$. This value is reached sooner in experiments characterized by faster $\mathrm{Fe}$ (II) oxidation; consequently, the large oversaturation with respect to schwertmannite kinetically favours this (meta)less stable mineral instead of tooeleite.

The formation of jarosite occurred after long term incubation in all biotic and abiotic experiments. This suggests that jarosite was not precipitated directly upon bacterial iron oxidation as opposed to tooeleite and As-rich schwertmannite. According to the second series of bioassays, the formation of this phase was favoured after complete $\mathrm{Fe}(\mathrm{II})$ oxidation, as Fe precipitation still proceeded after 20 days in a $\mathrm{pH}$ window $(\sim 1 \leq \mathrm{pH} \leq \sim 3)$ corresponding to the stability field of jarosite (Bigham et al., 1996). However, we cannot exclude the possibility that schwertmannite which is a metastable phase transform to jarosite upon increasing the aging time. Indeed, in experiments of Wang et al. (2006), schwertmannite produced by biological oxidation of ferrous iron in sulphate solutions has been shown to spontaneously transform to jarosite in the $\mathrm{pH}$ range 1.9-2.1 upon increasing the aging time from 19 to 40 days. Such a pH window corresponds to the conditions of our second series of bioassays $(2.15 \pm$ 0.06) which can provide the conditions of such transformation (Fig. 5c). 
The behaviour of $\mathrm{As}(\mathrm{V})$ and $\mathrm{As}(\mathrm{III})$ differed markedly while jarosite precipitation proceeded in the second stage of aging experiments (after 20 days in the second series of bioassays); $\mathrm{As}(\mathrm{V})$ remained immobilized in the precipitate whereas $\mathrm{As}(\mathrm{III})$ was released into solution (Fig. $6 \mathrm{~b}$ and $\mathrm{c}$ ). Thus, jarosite, which appears to be favoured at the expenses of tooeleite and As(III)-schwertmannite due to $\mathrm{pH}$ decrease upon increasing the aging time, is not an efficient sink for As (III) although it is known to incorporate $\mathrm{As}(\mathrm{V})$ to some extent (Paktunc and Dutrizac, 2003; Savage et al., 2005; Acero et al., 2006).

4.2. Consequences for in-situ formation of As-bearing phases at the Carnoulès mining site

The results of this study allow improving our knowledge on natural arsenic attenuation processes at the Carnoulès mining site evidenced in previous studies (Bruneel et al., 2003; Casiot et al., 2003; Morin et al., 2003). A. ferrooxidans, together with other iron oxidizers such as Gallionella ferruginea (Bruneel et al., 2006) promoted the oxidation of

(a)

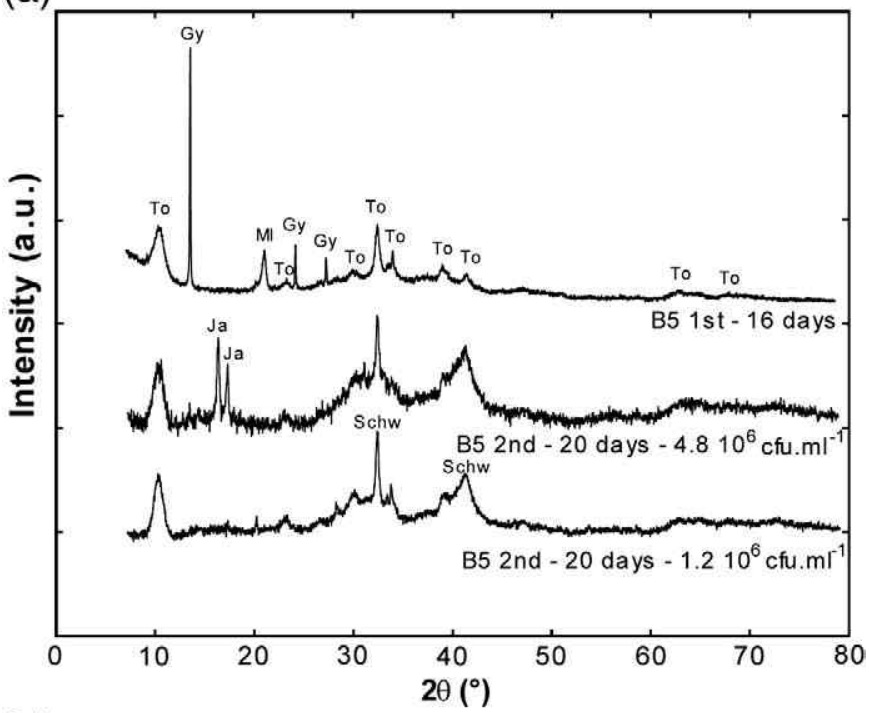

(b)

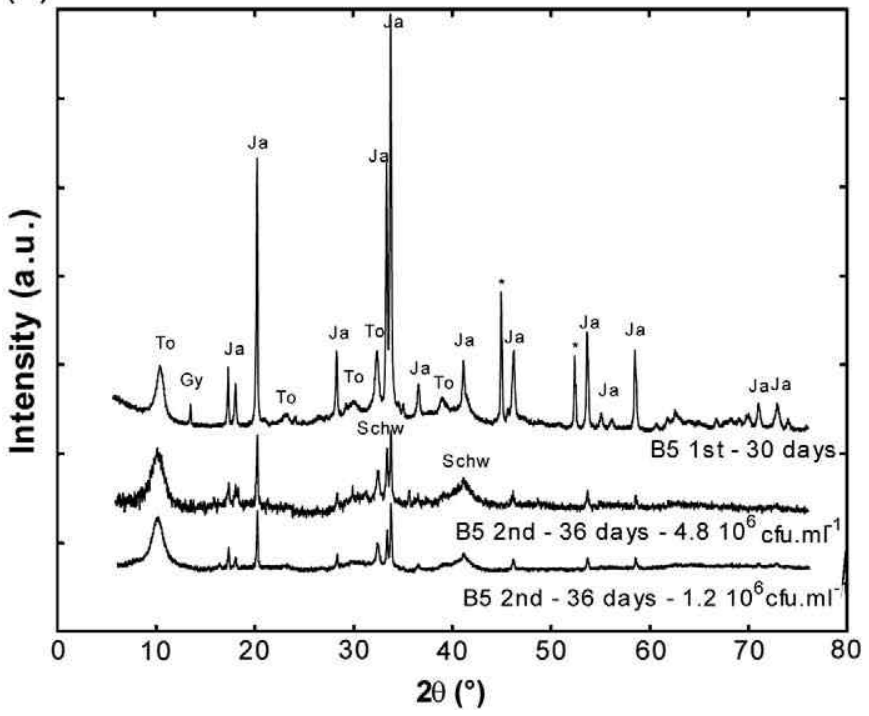

Fig. 8. Comparison between the X-ray powder diffraction patterns of the first and second bioassay samples. a) after 16-20 days incubation; b) after 30-36 days incubation. To: tooeleite; Ja: jarosite; Gy: gypsum; Ml: melanterite; Schw: schwertmannite. Since the amount of analyzed material varied from sample to sample, all data have been normalized to the first tooeleite peak intensity to facilitate qualitative comparison of the relative amount of the various phases in mixture in each sample.

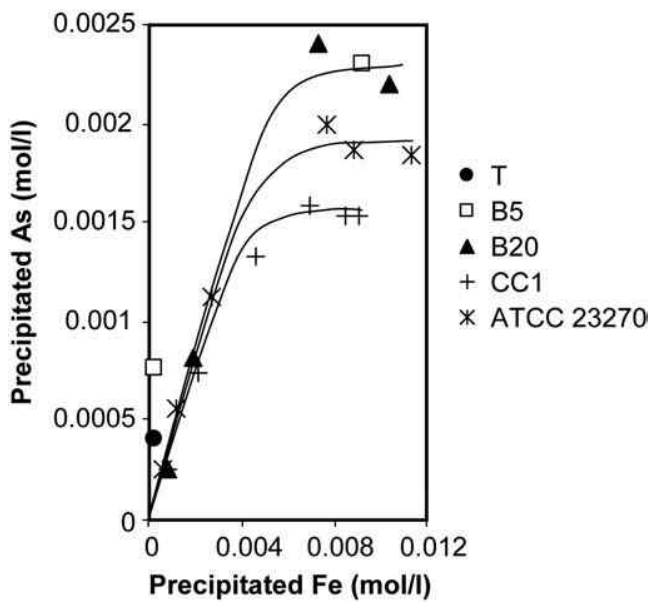

Fig. 9. Plots of cumulated concentration of precipitated As versus precipitated Fe for the different Acidithiobacillus ferrooxidans strains in the first bioassay.

$\mathrm{Fe}(\mathrm{II})$, which was entirely in the reduced form at the spring of the Reigous creek (Casiot et al., 2003). Fe(II)-oxidation products identified in the field were predominantly amorphous $\mathrm{Fe}(\mathrm{III})-\mathrm{As}(\mathrm{V})$ oxyhydroxides during the dry season (Morin et al., 2003). These phases represented no more than $10 \%$ of the As-bearing compounds in the first series of bioassays made with an AMD water that contained predominantly As(III). This result confirmed that the formation of amorphous $\mathrm{Fe}(\mathrm{III})-\mathrm{As}(\mathrm{V})$ oxyhydroxides involved the activity of bacterial strains able to oxidize As(III), which was not an ability of A. ferrooxidans. However, when $\mathrm{As}(\mathrm{V})$ was present in the spring water in the second series of bioassays, it was removed more efficiently than As(III) during Fe(II) oxidation. Thus, the rate of As (III) oxidation likely exert a strong influence on the mineralogy of Asrich $\mathrm{Fe}(\mathrm{II})$ oxidation products in the field.

During the wet season, the solid phases identified in the field were amorphous As(III)-Fe(III) oxy-hydroxides and tooeleite (Morin et al., 2003) at the acidic spring and As-coprecipitated schwertmannite few hundreds meters downstream (Casiot et al., 2005). These observations contrasted with the results of the present laboratory study. We may hypothesize that the formation of tooeleite in the field is favoured after dissolution of an amorphous As(III)-Fe(III) phase located in microbialites that can act as a precursor for tooeleite precipitation. Further laboratory experiments aiming at aging amorphous $\mathrm{As}(\mathrm{III})-\mathrm{Fe}$ (III) precipitates are needed to test this hypothesis.

\section{Conclusion}

Several bacterial strains of $A$. ferrooxidans have been evidenced to remove Fe and As efficiently from AMD water by coprecipitation of both elements in the form of As(III)-rich precipitates. The precipitates that formed in our batch experiments are composed of As(III)-Fe(III) amorphous phase, schwertmannite, jarosite and tooeleite, however the succession of the mineral phases that formed through time differed from one strain to another. It has been evidenced that several strains can favour the formation of tooeleite and its occurrence seems to be due to kinetic factors in the early stage of incubation. Indeed, slow kinetic rates lead to tooeleite precipitation whereas more rapid ones rather favour the precipitation of schwertmannite, both resulting from bacterial activity. Conversely, jarosite precipitates without the need for bacteria at the end of the experiments. Tooeleite is a very efficient scavenger for arsenic, particularly for As(III), and exhibits As/ Fe molar ratio higher than 0.5 . Thus, favouring the formation of this phase in remediation processes should improve the efficiency of As (III) retention. This might be achieved by the control of $\mathrm{Fe}(\mathrm{II})$ oxidation rate using A. ferrooxidans strains immobilised onto a solid matrix and may be the key point to favour the formation of stable 
tooeleite rather than $\mathrm{As}(\mathrm{III})$-rich schwertmannite, the latest being a less efficient scavenger for As(III) as the $\mathrm{pH}$ decreases.

\section{Acknowledgements}

This work was supported by the EC2CO-CYTRIX program from the Institut des Sciences de l'Univers (INSU-France), ANR (project "RARE") and by SESAME IdF grant \#1775. Portions of this research were carried out at SSRL, a national user facility operated by Stanford University on behalf of the U.S. Department of Energy, Office of Basic Energy Sciences. We acknowledge SSRL, ESRF, and LURE for provision of beamtime on beamlines 11-2, BM30B, and D44, respectively. Strains CC1 and ATCC 23270 were obtained from the same site and kindly donated by Violaine Bonnefoy of the Laboratoire de Chimie Bactérienne, Marseille.

\section{References}

Acero, P., Ayora, C., Torrento, C., Nieto, J.M., 2006. The behavior of trace elements during schwertmannite precipitation and subsequent transformation into goethite and jarosite. Geochim. Cosmochim. Acta 70, 4130-4139.

Bigham, J.M., Schwertmann, U., Traina, S.J., Winland, R.L., Wolf, M., 1996. Schwertmannite and the chemical modeling of iron in acid sulfate waters. Geochim. Cosmochim. Acta 60 (12), 2111-2121.

Blanc, P., Lassin, A., Piantone, P., 2007. Thermoddem a database devoted to waste minerals. BRGM, (Orléans, France).

Bruneel, O., Personne, J.-C., Casiot, C., Leblanc, M., Elbaz-Poulichet, F., Mahler, B.J., Le Fleche, A Grimont, P.A.D., 2003. Mediation of arsenic oxidation by Thiomonas sp. in acid-mine drainage (Carnoulès, France). J. Appl. Microbiol. 95, 492-499.

Bruneel, O., Duran, R., Casiot, C., Elbaz-Poulichet, F., Personné, J.-C., 2006. Diversity of microorganisms in Fe-As-rich acid mine drainage waters of Carnoulès, France. Appl. Environ. Microbiol. 72 (1), 551-556.

Cancès, B., Juillot, F., Morin, G., Laperche, V., Alvarez, L., Proux, O., Hazemann, J.L., Brown, G.E., Calas, G., 2005. XAS evidence of As(V) association with iron oxyhydroxides in contaminated soil at a former arsenical pesticide processing plant. Environ. Sci. Technol. 39 (24), 9398-9405.

Cancès, B., Juillot, F., Morin, G., Laperche, V., Polya, D., Vaughan, D.J., Hazemann, J.L., Proux, O., Brown Jr., G.E., Calas, G., 2008. Changes in arsenic speciation through a contaminated soil profile: A XAS based study. Sci. Total Environ. 397 (1-3), 178-189.

Carlson, L., Bigham, J.M., Schwertmann, U., Kyek, A., Wagner, F., 2002. Scavenging of As from acid mine drainage by schwertmannite and ferrihydrite: a comparison with synthetic analogues. Environ. Sci. Technol. 36, 1712-1719.

Casiot, C., Morin, G., Juillot, F., Bruneel, O., Personné, J.-C., Leblanc, M., Duquesne, K., Bonnefoy, V., Elbaz-Poulichet, F., 2003. Bacterial immobilization and oxidation of arsenic in acid mine drainage (Carnoules creek, France). Water Res. 37, 2929-2936.

Casiot, C, Lebrun, S., Morin, G. Bruneel, O, Personné, J-C, Elbaz-Poulichet, F, 2005. Sorption and redox processes controlling arsenic fate and transport in a stream impacted by acid mine drainage. Sci. Total Environ. 347, 122-130.

Cesbron, F.P., Williams, S.A., 1992. Tooeleite, a new mineral from the U.S. Mine, Tooele County, Utah. Mineral. Mag. 56, 71-73.

Demchak, J., Skousen, J., McDonald, L.M., 2004. Longevity of acid discharges from underground mines located above the regional water table. J. Environ. Qual. 33, $656-668$

Dixit, S., Hering, J.G., 2003. Comparison of arsenic(V) and arsenic(III) sorption onto iron oxide minerals: implications for arsenic mobility. Environ. Sci. Technol. 37, 4182-4189.

Duquesne, K., Lebrun, S., Casiot, C., Bruneel, O., Personné, J.-C., Leblanc, M., Elbaz-Poulichet F., Morin, G., Bonnefoy, V., 2003. Immobilization of arsenite and ferric iron by Acidithiobacillus ferrooxidans and its relevance to acid mine drainage. Appl. Environ. Microbiol. 60 (10), 6165-6173.

Filipek, L.H., Nordstrom, D.K., Ficklin, W.H., 1987. Interaction of acid mine drainage with waters and sediments of West Squaw Creek in the West Shasta District, California. Environ. Sci. Technol. 21, 388-396.

Fortin, D., Ferris, F.G., Scott, S.D., 1998. Formation of Fe-silicates and Fe-oxides on bacterial surfaces in samples collected near hydrothermal vents on the Southern Explorer Ridge in the northeast Pacific Ocean. Am. Mineral. 83, 1399-1408.

Johnson, D.B., Hallberg, K.B., 2005. Acid mine drainage remediation options: a review. Sci. Total Environ. 338, 3-14.
Jones, B., Renaut, R.W., 2007. Selective mineralization of microbes in Fe-rich precipitates (jarosite, hydrous ferric oxides) from acid hot springs in the Waiotapu geothermal area, North Island, New Zealand. Sediment. Geol. 194, 77-98.

Kasama, T., Murakami, T., 2001. The effect of microorganisms on Fe precipitation rates at neutral pH. Chem. Geol. 180, 117-128.

Langmuir, D., Mahoney, J., Rowson, J., 2006. Solubility products of amorphous ferric arsenate and crystalline scorodite $(\mathrm{FeAsO} \cdot 2 \mathrm{H} 2 \mathrm{O})$ and their application to arsenic behavior in buried mine tailings. Geochim. Cosmochim. Acta 70, 2942-2956.

Lebrun, S., 2005. Minéralogie des précipités hydratés Fe-As dans un drainage minier acide: Rôle des microorganismes acidophiles. Université Pierre et Marie Curie, Paris, France.

Lopez-Archilla, A.I., Marín, I., Amils, R., 2001. Microbial community composition and ecology of an acidic aquatic environment: the Tinto River, Spain. Microb. Ecol. 41, $20-35$.

Morin, G., Calas, G., 2006. Arsenic in soils, mine tailings, and former industrial sites. Elements 2 (2), 97-101.

Morin, G., Juillot, F., Casiot, C., Bruneel, O., Personné, J.-C., Elbaz-Poulichet, F., Leblanc, M., Ildefonse, P., Calas, G., 2003. Bacterial Formation of tooeleite and mixed arsenic(III) or arsenic(V)-iron(III) gels in the Carnoulès acid mine drainage, France. A XANES, XRD, and SEM Study. Environ. Sci. Technol. 37, 1705-1712.

Morin, G., Rousse, G., Elkaim, E., 2007. Crystal structure of tooeleite, Fe6(AsO3)4SO4 $(\mathrm{OH}) 4 \cdot 4 \mathrm{H} 2 \mathrm{O}$, a new iron arsenite oxyhydroxysulfate mineral relevant to acid mine drainage. Am. Mineral. 92, 193-197.

Nishimura, T., Robins, R.G., 2008. Confirmation that tooeleite is a ferric arsenite sulfate hydrate, and is relevant to arsenic stabilisation. Miner. Eng. 21, 246-251.

Nordstrom, D.K., Alpers, C.N., 1999. Geochemistry of acid mine waters. In: Plumlee, G.S., Logsdon, M.J. (Eds.), The Environmental Geochemistry of Mineral Deposits, Part A. Processes, Techniques, and Health Issues: Society of Economic Geologists, Reviews in Economic Geology, vol. 6A, pp. 133-156.

Olías, M., Cánovas, C.R., Nieto, J.M., Sarmiento, A.M., 2006. Evaluation of the dissolved contaminant load transported by the Tinto and Odiel rivers (South West Spain). Appl. Geochem. 21 (10), 1733-1749.

Ona-Nguema, G., Morin, G., Juillot, F., Calas, G., Brown, G.E., 2005. EXAFS analysis of arsenite adsorption onto two-line ferrihydrite, hematite, goethite, and lepidocrocite. Environ. Sci. Technol. 39 (23), 9147-9155.

Paktunc, D. Dutrizac, J., Gertsman, V. 2008. Synthesis and phase transformations involving scorodite, ferric arsenate and arsenical ferrihydrite: implications for arsenic mobility. Geochim. Cosmochim. Acta 72, 2649-2672.

Paktunc, D., Dutrizac, J.E., 2003. Characterization of arsenate for sulfate substitution in synthetic jarosite using X-ray diffraction and X-ray absorption spectroscopy. Can. Mineral. 41 (4), 905-919.

Parkhurst, D.L., Appelo, C.A.J., 1999. User's guide to PHREEQC (Version 2) - a computer program for speciation, batch-reaction, one-dimensional transport, and inverse geochemical calculations, U.S. Geological Survey, Denver, Colorado.

Savage, K.S., Bird, D.K., O'Day, P.A., 2005. Arsenic speciation in synthetic jarosite. Chem. Geol. 215, 473-498.

Senko, J.M., Dewers, T.A., Krumholz, L.R., 2005. Effect of oxidation rate and Fe(II) state on microbial nitrate-dependent $\mathrm{Fe}$ (III) mineral formation. Appl. Environ. Microbiol. 71 (11), 7172-7177.

Wang, H., Bigham, J.M. Tuovinen, $\mathrm{O} . \mathrm{H}$, 2006. Formation of schwertmannite and its transformation to jarosite in the presence of acidophilic iron-oxidizing microorganisms. Mater. Sci. Eng., C 26, 588-592.

Warren, L.A., Ferris, F.G., 1998. Continuum between sorption and precipitation of Fe(III) on microbial surfaces. Environ. Sci. Technol. 32, 2331-2337.

Waychunas, G.A., Rea, B.A., Fuller, C.C., Davis, J.A., 1993. Surface chemistry of ferrihydrite: Part 1. EXAFS studies of the geometry of coprecipitated and adsorbed arsenate. Geochim. Cosmochim. Acta 57 (10), 2251-2269.

Waychunas, G.A., Xu, N., Fuller, C.C., Davis, J.A., Bigham, J.M., 1995. XAS study of AsO43and SeO42- substituted schwertmannites. Physica, B Condens. Matter 208-209, 481-483.

Winterer, M., 1997. XAFS: a data analysis program for material science. J. Phys. IV 7 (C2), 243-244.

Younger, P.L., Robins, N.S., 2002. Challenges in the characterization and prediction of the hydrogeology and geochemistry of mined ground. Geological Society, vol. 198(1). Special Publications, London, pp. 1-16.

Yu, J.-Y., Heo, B., Choi, I.-K., Cho, J.-P., Chang, H.-W., 1999. Apparent solubilities of schwertmannite and ferrihydrite in natural stream waters polluted by mine drainage. Geochim. Cosmochim. Acta 63 (19/20), 3407-3416.

Yu, J.-Y., McGenity, T.J., Coleman, M.L., 2001. Solution chemistry during the lag phase and exponential phase of pyrite oxidation by Thiobacillus ferrooxidans. Chem. Geol.175 (3-4), 307-317. 